\title{
Interleukin 10 suppresses experimental chronic, granulomatous inflammation induced by bacterial cell wall polymers
}

\author{
H H Herfarth, S P Mohanty, H C Rath, S Tonkonogy, R B Sartor
}

Chapel Hill, NC, USA

H H Herfarth

S P Mohanty

H C Rath

R B Sartor

College of Veterinary Medicine,

North Carolina State

University,

Raleigh, NC, USA

$S$ Tonkonogy

Correspondence to:

Dr R B Sartor,

Division of Digestive

Diseases,

$\mathrm{CB} \# 7080$,

Burnett-Womack Bldg,

University of North Carolina,

Chapel Hill,

NC 27599-7080, USA.

Accepted for publication

22 July 1996

Keywords: Interleukin 10, granuloma, inflammation, inflammatory bowel disease.

Inflammatory processes play a central part in mediating immune host defences to infectious pathogens and in wound healing, but an unrestrained, overly aggressive inflammatory response can induce inappropriate tissue destruction. Recent observations in animal models show that the chronicity of inflammation is determined by a dysregulated balance of pro and anti-inflammatory cytokines. ${ }^{1-3}$ Chronic immune mediated disorders like inflammatory bowel diseases (IBD), rheumatoid arthritis, and type I diabetes mellitus

\begin{abstract}
Departments of Medicine, Microbiology, and Immunology and Center for

Gastrointestinal

Biology and Disease, University of North Carolina,

Abstract

Background and Aims-Interleukin 10 (IL10) inhibits monocyte/macrophage and $T$ lymphocyte effector functions. This study examined the effect of systemically administered IL10 on acute and chronic granulomatous enterocolitis, hepatitis, and arthritis in a rat model.

Methods-Lewis rats were injected intramurally with streptococcal peptidoglycan-polysaccharide (PG-APS) polymers. Beginning 12 hours before PG-APS injection, rats were treated daily with subcutaneous murine recombinant IL10 or vehicle for three or 17 days.

Results-IL10 attenuated acute enterocolitis in a dose dependent fashion $(p<0 \cdot 01)$. Protective effects were more profound in the chronic granulomatous phase with decreased enterocolitis and markedly inhibited leucocytosis, hepatic granulomas, and chronic erosive arthritis $(p<0 \cdot 001)$. IL10 downregulated tissue IL1, IL6, tumour necrosis factor $\alpha$, and interferon $\gamma$ gene expression, consistent with the in vitro effects of IL10 on PG-APSstimulated splenocytes. Caecal IL1 protein concentrations and IL2 and interferon $\gamma$ secretion by in vitro stimulated mesenteric lymph nodes were downregulated in IL10 treated animals.

Conclusions-These results indicate that exogenous IL10 can inhibit experimental granulomatous inflammatory responses and suggest that IL10 treatment could be an effective new therapeutic approach in human disorders such as Crohn's disease, rheumatoid arthritis, and sarcoidosis.

(Gut 1996; 39: 836-845)
\end{abstract}

seem to arise from a genetically determined dysregulated immune response to ubiquitous antigens. ${ }^{4-6}$ Therefore immunomodulatory interventions that utilise endogenous immunosuppressive molecules provide an attractive, relatively non-toxic approach to treating these chronic, idiopathic disorders.

Interleukin 10 (IL10), originally named cytokine synthesis inhibitor factor, is a cytokine that inhibits many immune effector functions. IL10 is produced by a variety of cells including $T$ lymphocytes, $B$ cells, and macrophages and suppresses the in vitro production of interferon (IFN) $\gamma$ and IL2 by Th1 lymphocytes and IL1, IL6, IL8, tumour necrosis factor (TNF) $\alpha$, granulocyte-macrophage colony stimulating factor, and granulocyte colony stimulating factor by monocytes/macrophages. ${ }^{78}$

Several in vivo findings in experimental animal models suggest that IL10 is an important anti-inflammatory agent. Increased IL10 gene expression correlates with recovery in experimental autoimmune encephalomyelitis ${ }^{9}$ and recombinant IL10 treatment attenuates the clinical course of this disease. ${ }^{10}$ Spontaneous intestinal inflammation occurs in IL10 deficient (knockout) mice $^{11}$ and continuous administration of IL10 attenuates experimental colitis in a lymphocyte transfer model. ${ }^{12}$ Furthermore, IL10 therapy prevents early death and pancreatic necrosis in models of experimental endotoxaemia ${ }^{13}$ and acute pancreatitis ${ }^{14}$ respectively, probably by down regulating TNF $\alpha$. Finally, blockade of endogenous IL10 increases the severity of experimental arthritis in mice. ${ }^{15}$

Peptidoglycan-polysaccharide (PG-PS) polymers, the basic structural component of the cell walls of Gram positive and Gram negative bacteria, induce acute inflammation, which in the susceptible host proceeds into a relapsing, granulomatous inflammatory reaction in several organs. ${ }^{16-19}$ The granulomatous enterocolitis model in susceptible Lewis rats is characterised by chronic, transmural, spontaneously relapsing intestinal inflammation, accompanied by hepatic granulomas, erosive arthritis, chronic anaemia, and leucocytosis. ${ }^{17}$ Inflammation is induced by subserosal (intramural) injection of PG-PS from group A Streptococcus pyogenes (PG-APS) into the terminal ileum and caecum. Inflammation in this model follows a biphasic course. The acute phase of focal intestinal inflammation peaks one to three days after PG-APS injection, then gradually resolves, but is followed after 10-14 days by a spontaneous 
reactivation with extensive granulomatous intestinal and systemic inflammation. ILl is involved in the pathogenesis of acute and chronic phases of this model because caecal IL1 concentrations are increased and IL1 receptor antagonist (IL1 RA) treatment attenuates inflammation. ${ }^{17} \mathrm{~T}$ lymphocytes are necessary for the chronic granulomatous phase of PG-APS induced inflammation, as cyclosporin A completely prevents chronic inflammation and granuloma formation in the gut, liver and joints, and athymic animals fail to develop chronic inflammation after PG-APS injection. ${ }^{20-22}$

Because $\mathrm{T}$ lymphocytes and pro-inflammatory cytokines such as ILl are involved in the pathogenesis of intestinal, liver, and joint inflammation in the PG-APS model, we postulated that IL10 therapy should exert a protective effect. In this study we examined the ability of recombinant murine IL10 to prevent intestinal and systemic inflammation in the PG-APS enterocolitis model and investigated the in vivo and in vitro effects of IL10 on the regulation of key pro-inflammatory cytokines.

\section{Methods}

\section{Animals and reagents}

Female, inbred specific pathogen free Lewis rats (145-155 g) were obtained from Charles River Laboratories (Raleigh, NC). Rats were fed Agway Prolab rat chow (Agway, Syracuse, NY) ad libitum and were weighed daily. All rat experiments were conducted in accord with the highest standards of humane animal care as outlined in the National Institutes of Health's Guide for the Care and Use of Laboratory Animals and approved by the University of North Carolina Institutional Animal Care and Use Committee.

Recombinant murine IL10 (Batch 3-mIL 10-3 specific activity $65 \times 10^{6} \mathrm{U} / \mathrm{mg}$; Batch 3-mIL 10-5 specific activity $45 \times 10^{6} \mathrm{U} / \mathrm{mg}$ ) was obtained from Schering-Plough Research Institute (Kenilworth, NJ).

\section{Preparation of PG-APS}

Purified, sterile PG-APS fragments from the cell walls of group A, type 3, strain D58 streptococci (Streptococcus pyogenes) were prepared as described previously ${ }^{23}$ and provided by Roger Brown and Dr John Schwab (Department of Immunology and Microbiology, University of North Carolina, Chapel Hill). Sonicated cell wall fragments by this method have molecular weights ranging from $5 \times 10^{6}$ to $5 \times 10^{8} .{ }^{23}$ The final PG-APS concentration was calculated based on rhamnose content. ${ }^{23}$

\section{Cytokine expression in vitro by splenocytes from \\ Lewis rats}

Splenocytes $\left(5 \times 10^{6}\right.$ cells $\left./ \mathrm{ml}\right)$ were cultured for six hours in the presence of PG-APS (50 $\mu \mathrm{g} / \mathrm{ml})$ and $\operatorname{IL} 10(0,1,5,50$ or $250 \mathrm{ng} / \mathrm{ml})$. The culture medium was RPMI 1640 supplemented with $5 \%$ heat inactivated fetal calf serum, $2 \mathrm{mM}$ glutamine, $5 \times 10^{-6} \mathrm{M}$ 2-mercaptoethanol, 100 units/ml penicillin $\mathrm{G}$, $1000 \mu \mathrm{g} / \mathrm{ml}$ streptomycin sulphate, and 0.25 $\mu \mathrm{g} / \mathrm{ml}$ amphotericin B. Total RNA was isolated using Trizol (Gibco, Grand Island, MY) and stored at $-80^{\circ} \mathrm{C}$ until further processing.

\section{Induction of enterocolitis by PG-APS}

Lewis rats, randomised into treatment groups, were anaesthetised $(20 \mu \mathrm{l} / 100 \mathrm{~g}$ by intramuscular injection Innovar-Vet; Pitman Moore, Washington Crossing, NJ), and intestines were exposed by laparotomy using aseptic technique. Rats were injected subserosally with PG-APS using a total dose of $12.5 \mu \mathrm{g} / \mathrm{g}$ body weight rhamnose (equivalent to $37.5 \mu \mathrm{g}$ dry wt PG-APS/g body weight) distributed among seven injection sites in the ileal Peyer's patches, terminal ileum, and caecum as previously described. ${ }^{24}$ Control rats received identical injections of $37.5 \mu \mathrm{g} / \mathrm{g} /$ body weight human serum albumin (HSA) (Baxter Health Care Corp, Glendale, CA).

\section{IL10 treatment and experimental design}

Recombinant murine IL10 was administered by subcutaneous injection in different concentrations $(100 \mu \mathrm{g}$ or $250 \mu \mathrm{g} / \mathrm{kg} / 24 \mathrm{~h}$ in the acute phase experiment or $125 \mu \mathrm{g} / \mathrm{kg} / 12 \mathrm{~h}$ in the chronic phase experiment) in $0.3 \mathrm{ml}$ sterile $\mathrm{NaCl}$. Control PG-APS and HSA injected animals received rat serum albumin (RSA) (Sigma, St Louis, MO) subcutaneously in different concentrations $(250 \mu \mathrm{g} / \mathrm{kg} / 24 \mathrm{~h}$ in the acute phase experiment or $125 \mu \mathrm{g} / \mathrm{kg} / 12 \mathrm{~h}$ in the chronic phase experiment) dissolved in $0.3 \mathrm{ml}$ sterile $\mathrm{NaCl}$. In both studies treatment was started 12 hours before PG-APS or HSA intramural injection and given for the next three or 17 days respectively, in the above described scheme.

\section{Clinical assessment of inflammation and} harvesting of tissues

After three (acute phase) or 17 (chronic phase) days all rats were killed by inhalation of $100 \%$ $\mathrm{CO}_{2}$. Cardiac blood was obtained for cell counts, which were processed using an automated cell counter. Liver and spleen weights were recorded and normalised for the individual rat body weight. Gross intestinal inflammation was scored by a single blinded observer using a previously validated method. ${ }^{17}$ Values of $0-4$ ( 4 being the most severe) were assigned to the (a) presence of caecal serosal nodules, (b) severity of contracted mesentery, (c) severity of adhesions, and (d) extent of caecal bowel wall thickening. The resulting 'gross gut score' is the sum of these values, the maximum possible being 16. Additionally the macroscopically visible number of liver granulomas was assessed by assigning a value from 0-4. Caecal, mesenteric lymph node and liver tissues were snap frozen in isopentane and kept at $-80^{\circ} \mathrm{C}$ for later mRNA and protein analysis. Samples of the liver, terminal ileum, caecum, 
and joints from each animal were fixed in formalin, embedded in paraffin wax, and sectioned for histochemical staining (haematoxylin and eosin).

\section{Monitoring of arthritis}

Arthritis was monitored clinically (erythema, swelling) and by measuring the diameters of both rear ankle joints with a Fowler Ultra-Cal. II caliper (Lux Scientific Instrument Corp, New York, NY) as described previously. ${ }^{23} 25$ Joints were measured before PG-APS injection and serially thereafter. To reduce bias, all groups were coded, and the rats were selected randomly from the cages, so that no identification was visible to the person making the measurements. Data were expressed as the increase of joint diameter in $\mathrm{mm}$ compared with the baseline measurement before PG-APS or HSA injection.

\section{Histological and biochemical evaluation of inflammation}

A histological inflammatory score was evaluated for each animal by a blinded observer as described previously. ${ }^{17}$ Briefly, values from 0-4 (4 being the most severe) were assigned for both acute and chronic inflammation in the different layers of the intestine in coded cross sections of the terminal ileum, mid caecum, and caecal tip. The acute and chronic scores of each animal were totalled, a score of 24 representing the maximum possible histological inflammatory score.

\section{Measurement of myeloperoxidase activity}

Caecal myeloperoxidase (MPO) activity was determined using a modified standard method. ${ }^{26}$ Briefly, caecal tissue was homogenised in $4 \mathrm{ml}$ $20 \mathrm{mmol} / 1$ phosphate buffer $(\mathrm{pH} \mathrm{7.4})$ and centrifuged at $4000 \mathrm{rpm}$ at $4^{\circ} \mathrm{C}$ for 20 minutes. The pellet was homogenised and sonicated with $2 \mathrm{ml} 50 \mathrm{mmol} / \mathrm{l}$ acetic acid (pH 6) containing $0.5 \%(\mathrm{wt} / \mathrm{vol})$ hexadecyltrimethylammonium hydroxide. MPO activity of the supernatant was determined by measuring the $\mathrm{H}_{2} \mathrm{O}_{2}$ dependent oxidation of 3,3',5,5'-tetramethylbenzidine and expressed as units per gram of tissue.

TABLE I Oligonucleotide primers used for amplification of different cytokines by RT-PCR

\begin{tabular}{|c|c|c|c|}
\hline$m R N A$ & 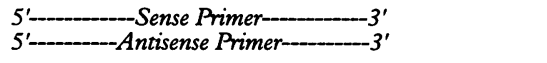 & $\begin{array}{l}\text { Sample } \\
\text { cDNA }\end{array}$ & $\begin{array}{l}\text { Annealing } \\
\text { temperature }\end{array}$ \\
\hline $\mathrm{IFN} \gamma$ & $\begin{array}{l}\text { 5'-AAG ACA ACC AGG CCA TCA GCA-3' } \\
\text { 5'-AGC CAC AGT GTG AGT TCA GTC-3' } \\
\text { 5'-ATG GAA GGA AAG AGC CTC CTC-3' } \\
\text { 5'-CTT GGC GAT GCT CAT GAA TGC-3' }\end{array}$ & $\begin{array}{l}547 \mathrm{bp} \\
225 \mathrm{bp}\end{array}$ & $\begin{array}{l}60^{\circ} \mathrm{C} \\
60^{\circ} \mathrm{C}\end{array}$ \\
\hline $\mathrm{TNF} \alpha$ & $\begin{array}{l}\text { 5'-CAC CAT GAG CAC GGA AAG CA-3' } \\
\text { 5'-GCA ATG ACT CCA AAG TAG ACC-3' }\end{array}$ & $692 \mathrm{bp}$ & $58^{\circ} \mathrm{C}$ \\
\hline IL6 & $\begin{array}{l}\text { 5'-CTT CCA GCC AGT TGC CTT CT-3' } \\
\text { 5'-GAG AGC ATT GGA AGT TGG GG-3' }\end{array}$ & $504 \mathrm{bp}$ & $60^{\circ} \mathrm{C}$ \\
\hline $\operatorname{IL} 1 \alpha$ & $\begin{array}{l}\text { 5'-TCC TGT GAC TCT CAA AGT CTC-3' } \\
\text { 5'-ATG CGA GTG ACT TAG GAC GA-3 }\end{array}$ & $362 \mathrm{bp}$ & $58^{\circ} \mathrm{C}$ \\
\hline IL $1 \beta$ & $\begin{array}{l}\text { 5'-GCT ACC TAT GTC TTG CCC GT-3' } \\
\text { 5'-GAC CAT TGC TGT TTC CTA GG-3' }\end{array}$ & $543 \mathrm{bp}$ & $58^{\circ} \mathrm{C}$ \\
\hline IL1 RA & $\begin{array}{l}\text { 5'-CTG GGA TAC TAA CCA GAA GAC C-3' } \\
\text { 5'-TGG TGT GTT GGT GAG GCT CAC-3' }\end{array}$ & $367 \mathrm{bp}$ & $58^{\circ} \mathrm{C}$ \\
\hline$\beta$ actin & $\begin{array}{l}\text { 5'-ACC ACA GCT GAG AGG GAA ATC G-3' } \\
\text { 5'-AGA GGT CTT TAC GGA TGT CAA CG-3' }\end{array}$ & $281 \mathrm{bp}$ & $60^{\circ} \mathrm{C}$ \\
\hline
\end{tabular}

\section{$R N A$ preparation}

Total tissue RNA was prepared using a standard method with guanidine thiocyanatecesium chloride as previously described. ${ }^{17}$ Total RNA was quantified by ultraviolet spectrophotometry (A260/A280). The integrity and quality of each RNA sample was checked by electrophoresis on a $1 \%$ agarose gel containing ethidium bromide.

\section{Polymerase chain reaction (PCR)}

For each sample $1 \mu \mathrm{g}$ of total RNA was reverse transcribed in a total volume of $25 \mu \mathrm{l}$ containing $1 \times$ first strand buffer (Gibco, Grand Island, NY) $125 \mathrm{U}$ of Moloney murine leukaemia virus RT (Gibco, Grand Island, NY), 15 U RNAse inhibitor (Promega, Madison, WI), $0.5 \mathrm{mM}$ each of four dNTPs (Pharmacia, Piscataway, NJ), and $5 \mathrm{pmol}$ of random Hexamers (Pharmacia, Piscataway, NJ). The reaction was carried out at $39^{\circ} \mathrm{C}$ for one hour, followed by $93^{\circ} \mathrm{C}$ for seven minutes, $24^{\circ} \mathrm{C}$ for one minute, and finally cooled down to $4^{\circ} \mathrm{C}$ for 30 minutes. The reaction mixture was stored at $-20^{\circ} \mathrm{C}$ until further use.

The amplification was carried out in a 9600 Perkin-Elmer cycler (Applied Biosystem, Foster City, CA). One to $2 \mu \mathrm{l}$ of cDNA sample was amplified in $50 \mu \mathrm{l}$ of a reaction mixture containing $1 \times$ Taq buffer II (Perkin Elmer, Norwalk, Co), $1.5 \mathrm{mM} \mathrm{MgCl}, 2 \mu \mathrm{M}$ each of $5^{\prime}$ and $3^{\prime}$ primers and $1 \mathrm{U}$ of TAQ polymerase (Perkin Elmer, Norwalk, CO). Samples were heated for four minutes at $94^{\circ} \mathrm{C}$ and the following cycles were conducted at $94^{\circ} \mathrm{C}$ for 45 seconds, $60^{\circ} \mathrm{C}$ for 45 seconds, $72^{\circ} \mathrm{C}$ for 1.30 minutes. At the end the reaction mix was held at $72^{\circ} \mathrm{C}$ for five minutes. Negative controls without cDNA were amplified with each PCR experiment. To confirm that equal amounts of RNA were added in each PCR within an experiment and to verify a uniform amplification process $\beta$ actin mRNA was reverse transcribed and amplified in each assay. Aliquots of the samples were analysed by electrophoresis on a $2 \%$ agarose gel containing ethidium bromide. The DNA products were visualised by ultraviolet fluorescence and photographs of the gels were taken with a negative film (Polaroid 665, Polaroid Corp, Cambridge, MA). The negative was scanned with a Silverscanner II PS v2.1a using Adobe Photoshop 2.5.1 software.

Primers specific for rat cytokines were constructed according to published sequences ${ }^{27-33}$ and are listed in Table I. The authenticity of the PCR product was confirmed by comparing actual and predicted size using a $100 \mathrm{bp}$ DNA ladder (Gibco) and by observation of fragments of predicted sizes after digestion with the listed restriction enzymes: EcoR I (IFN $\gamma$ ), TAQ I (TNF $\alpha$, IL1 RA), BgI II (IL6), Acc I (ILl $\alpha$ ), BamH I (IL $\beta$ ).

Cell cultures of mesenteric lymph nodes (MLN) Mesenteric lymph nodes from rats treated with IL10 or the vehicle were removed, gently minced, and filtered through a fine mesh. 
The cells were washed and resuspended $\left(5 \times 10^{6}\right.$ in $\left.1 \mathrm{ml}\right)$ in RPMI and additives as described above. The cells were cultured at $37^{\circ} \mathrm{C}$ in $5 \% \mathrm{CO}_{2}$ and $95 \% \mathrm{O}_{2}$ in a 24 well tissue culture plate for 10 or 36 hours in the presence or absence of concanavalin A $(1 \mu \mathrm{g} / \mathrm{ml})$, after which the supernatants were collected for the assays. Experiments were performed with cells from at least three individual animals.

\section{Cytokine assays}

IL1 $\alpha$ : Caecal tissues were homogenised in ice cold $20 \mathrm{mmol} / \mathrm{l}$ phosphate buffer $(\mathrm{pH} \mathrm{7.4})$ and the supernatant kept at $-80^{\circ} \mathrm{C}$ until assay. The homogenates were measured in 1:1 dilutions using a radioimmunoassay kit for rat $\mathrm{ILl} \alpha$ (Cytokine Science, Boston, MA).

IFN $\gamma$ activity was measured by a rat IFN $\gamma$ ELISA (Biosource Int; Camarillo, CA).

IL2 was measured in a bioassay using the murine cell line designated NK. Briefly, titrated amounts of culture supernatants were added to NK cells $\left(5 \times 10^{3}\right.$ cells/well in $100 \mu \mathrm{l}$ culture volume) and incubated for 48 hours. The cultures were pulsed with ${ }^{3} \mathrm{H}$-thymidine for the last four hours. Cells were harvested and incorporation of ${ }^{3} \mathrm{H}$-thymidine was determined by scintillation counting. Units per $\mathrm{ml}$ of IL2 are defined as the reciprocal of the dilution of supernatant that stimulates $50 \%$ of the maximal counts per minute of ${ }^{3} \mathrm{H}$-thymidine incorporation, multiplied by 10 as the bioassay volume is $0 \cdot 1 \mathrm{ml}$.

\section{Statistical analysis}

Data were analysed using a statistical software (Statview II; Abacus Concept, Berkely, CA). Differences between the groups were compared using one way analysis of variance or using $\chi^{2}$ analysis. Differences were considered significant if $\mathrm{p}$ values were $<0 \cdot 05$.
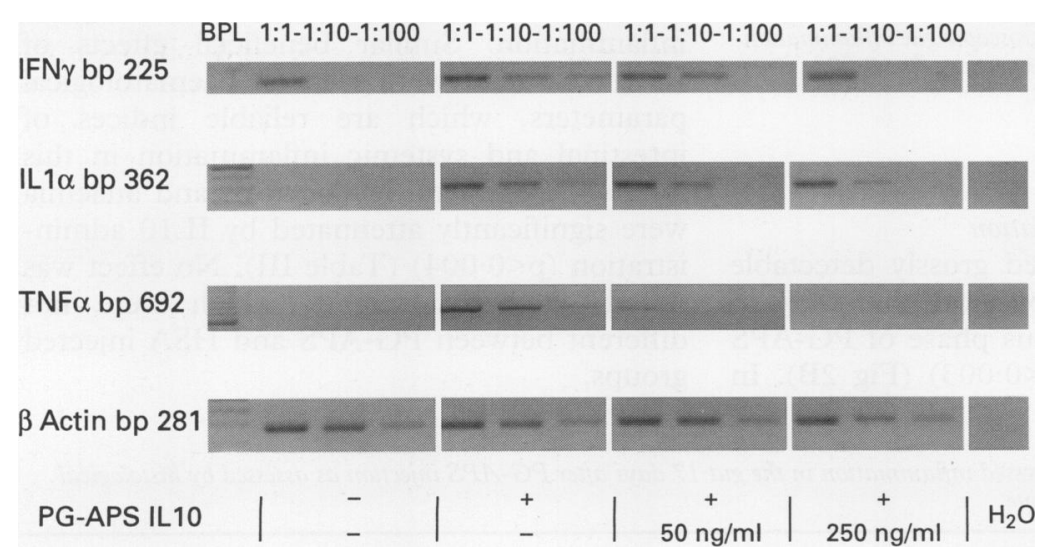

Figure 1: Semiquantitative RT-PCR analysis of the regulation of cytokine gene expression in isolated splenocytes by IL10. Splenocytes were isolated from Lewis rats and stimulated with $50 \mu \mathrm{g} / \mathrm{ml} P G-A P S$ with or without different concentrations of IL 10 (50 or $250 \mathrm{ng} / \mathrm{ml}$ ). with $50 \mu \mathrm{g} / \mathrm{ml} P G-A P S$ with or without different concentrations of IL $10(50$ or $250 \mathrm{ng} / \mathrm{ml})$
Total RNA was isolated after six hours, reverse transcribed, and the cDNA was diluted in 10-fold steps (1:1, 1:10, 1:100 for IL $1 \alpha, I F N \gamma$, TNF $\alpha$ or 1:10, 1:100, 1:1000 for Actin). Using specific oligonucleotide primers, amplification was performed for 35 (Actin, IL1 $\alpha$ ) or 40 cycles (IFN $\gamma, T N F \alpha$ ) and aliquots of the products were visualised on a $2 \%$ agarose gel with ethidium bromide. (BPL=100 base pair DNA ladder). Representative gels of three independent experiments are shown.

\section{Results}

In vitro inhibition of cytokines by IL10

To demonstrate the potential anti-inflammatory role of recombinant murine IL10 on rat cells stimulated with PG-APS, we isolated splenocytes from Lewis rats and added $50 \mu \mathrm{g} / \mathrm{ml}$ PG-APS and different concentrations of IL10 for six hours. PG-APS markedly upregulated IFN $\gamma$, IL $1 \alpha$, and TNF $\alpha$ gene expression in splenocytes in vitro (Fig 1). Fifty and $250 \mathrm{ng} / \mathrm{ml}$ recombinant murine IL10 inhibited gene expression of IFN $\gamma$, IL $1 \alpha$, and TNF $\alpha$ in a dose dependent fashion (Fig 1), whereas lower doses (1 or $5 \mathrm{ng} / \mathrm{ml}$ ) were ineffective (results not shown).

\section{Effects of IL10 treatment on the acute}

inflammatory phase

Two different doses of recombinant murine IL 10, 100 or $250 \mu \mathrm{g} / \mathrm{kg}$, were administered daily by subcutaneous injection, starting 12 hours before surgery. Three days after surgery, the rats were killed and the inflammatory changes of the intestine were scored in a blinded fashion. An amelioration of the gross gut score (GGS) with a significant benefit by the higher IL10 dose $(250 \mu \mathrm{g} / \mathrm{kg})$ was observed (Fig 2A). In the analysis of the different components of the GGS, the most significant improvement was in decreased caecal thickening (mean (SEM)) $(1.9(0.1)$ PG-APS/IL10 $250 \mu \mathrm{g} / \mathrm{kg}$ versus $2.3(0 \cdot 1) \quad$ PG-APS/RSA; $\mathrm{p}<0.01)$. Adhesions and mesenteric contractions improved with IL10 treatment, but were not significantly better than control values. Surprisingly, caecal MPO values were significantly increased with the higher IL10 dose compared with the control group $(p<0.05)$ (PG-APS/RSA: $4.5(0.4)$ units/g; PG-APS/ IL10 $100 \mu \mathrm{g} / \mathrm{kg}: 5 \cdot 7(0 \cdot 6)$ units $/ \mathrm{g}$; PGPS/IL10 $250 \mu \mathrm{g} / \mathrm{kg}: 6.0(0.4)$ units/g; HSA/RSA: 3.1 $(0.5)$ units/g) and histological examination of selected animals showed no difference between the IL10 treated and untreated PG-APS injected groups (results not shown). IL10 treatment ameliorated the acute arthritis, but the differences between the groups were not significant due to the low incidence of acute arthritis after intestinal intramural PG-APS injection. ${ }^{17}$ Furthermore, there were no differences in body weight, liver weight, packed cell volume or white blood cell count between the groups.

\section{Effects of IL10 on the chronic inflammatory}

phase

Using the higher IL10 dose $(250 \mu \mathrm{g} / \mathrm{kg} / 24 \mathrm{~h})$, which exhibited greater protective effects on gross intestinal inflammation in the acute phase, we investigated whether continuous IL10 administration for 17 days had a protective effect in the T lymphocyte dependent, chronic phase of this model. Because a recently published study showed better effects of IL10 treatment when given at shorter time intervals, ${ }^{34}$ we administered divided doses of IL10 $(125 \mu \mathrm{g} / \mathrm{kg} / 12 \mathrm{~h})$. 

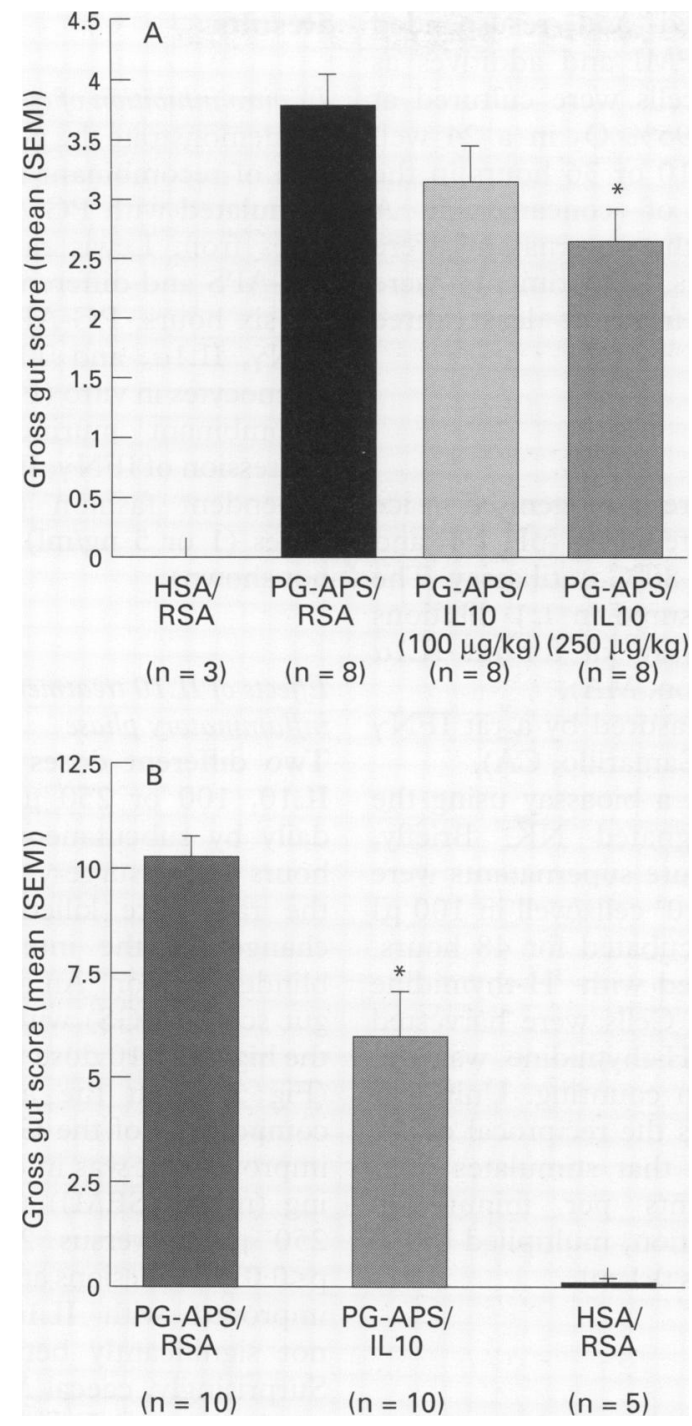

Figure 2: (A) In vivo administration of IL10 (100 $\mu \mathrm{g} / \mathrm{kg}$ or $250 \mu \mathrm{g} / \mathrm{kg}$ every 24 hours subcutaneously) shows a dose dependent effect on acute intestinal inflammation in the PG-APS model. IL10 or RSA treatment was started 12 hours before subserosal PG-APS or HSA injection and then was continued for three days. The gross gut score was made by a single blinded observer at necropsy on day 3. $H S A=$ human serum albumin; $R S A=$ rat serum albumin; $P G-A P S=$ peptidoglycan-polysaccharide polymers

isolated from group $A$ Streptococcus pyogenes. ${ }^{*} p<0.01$ $P G-A P S / I L 10$ v PG-APS/RSA. (B) In vivo subcutaneous administration of IL 10 (125 $\mu \mathrm{g} / \mathrm{kg}$ every 12 hours) significantly reduces chronic macroscopic gut inflammation 17 days after $P G-A P S$ or $H S A$ injection. ${ }^{\star} p<0.003$ $P G-A P S / I L 10$ v PG-APS/RSA.

\section{Chronic intestinal inflammation}

IL10 significantly reduced grossly detectable intestinal inflammation by more than $40 \%$ in the chronic granulomatous phase of PG-APS induced enterocolitis $(p<0.003)$ (Fig 2B). In contrast with the acute phase significant improvement was observed in all parameters of the gross gut score, including thickening of the bowel wall, caecal nodules, intestinal adhesions, and mesenteric contractions. By histological assessment significant differences were seen between the treated and untreated PG-APS injected groups in both the acute (neutrophilic cell infiltration and abscess formation) and chronic components (mononuclear cell infiltration and granuloma formation) (Table II). IL10 treatment resulted in a $30 \%$ decrease in the total (summed) histological inflammatory score $(p<0.03)$. The improvement of the acute score with IL10 treatment was more pronounced in the terminal ileum than in the caecum, where only a trend could be observed. The small suppression of neutrophil infiltration in the caecum by IL10 was also reflected by caecal MPO values, which showed only a slight, non-significant improvement in the treatment group (PG-APS/RSA: $12 \cdot 1$ $(1 \cdot 0)$ units/g; PG-APS/IL10 $250 \mu \mathrm{g} / \mathrm{kg}: 11 \cdot 8$ $(1 \cdot 7)$ units/g; HSA/RSA: 2.7 (0.5 units/g).

Chronic extraintestinal inflammation

Extraintestinal inflammation was inhibited by IL10 to a greater extent than enterocolitis. Eighty per cent of the PG-APS/RSA group had macroscopically visible liver granulomas, compared with only two of 10 animals in the PG-APS/IL10 group $(p<0.001)$. Histological analysis showed that one additional IL10 treated rat had scattered hepatic granulomas, which were not visible by macroscopic evaluation (Table III). However, these three IL10 treated animals showed considerably less hepatic inflammation than the PG-APS/RSA animals in regard to histological distribution and destruction of liver parenchyma. Although parenchymal granulomas were only rarely seen in the liver of IL10 treated rats, a mononuclear cell infiltrate was observed around bile ducts (Fig 3). The increase in liver weight of PG-APS injected/IL10 treated rats compared with non-PG-APS injected controls was decreased by $45 \%(p<0.03)$ (Table III), confirming a beneficial effect of IL10 on hepatic inflammation. Similar beneficial effects of IL10 treatment were seen on haematological parameters, which are reliable indices of intestinal and systemic inflammation in this model. ${ }^{17}$ Peripheral leucocytosis and anaemia were significantly attenuated by IL10 administration $(p<0.004)$ (Table III). No effect was noted on body weights, which were not different between PG-APS and HSA injected groups.

TABLE II IL10 treatment suppressed inflammation in the gut 17 days after PG-APS injection as assessed by histological inflammatory scores of the intestine

\begin{tabular}{|c|c|c|c|c|c|c|c|}
\hline \multirow{2}{*}{$\begin{array}{l}\text { Groups } \\
\text { Gut injection/treatment }\end{array}$} & \multicolumn{2}{|c|}{ Terminal ileum } & \multicolumn{2}{|l|}{ Caecum } & \multicolumn{3}{|c|}{ Histological inflammatory score } \\
\hline & acute & chronic $^{\star}$ & acute & chronic & acute $\dagger$ & chronic & Histological scores $\ddagger$ \\
\hline $\begin{array}{l}\text { PG-APA/RSA }(n=10) \\
\text { PG-APS/IL10 }(n=10) \\
\text { HSA/RSA }(n=5) \\
\text { p Value } \$\end{array}$ & $\begin{aligned} & 3.8(0 \cdot 1) \\
& 2.4(0.6) \\
0 & \\
< & 0.03\end{aligned}$ & $\begin{array}{l}3.7(0.8) \\
2 \cdot 6(0.4) \\
0 \\
<0.02\end{array}$ & $\begin{array}{l}7 \cdot 0(0 \cdot 2) \\
5 \cdot 1(1 \cdot 1) \\
0\end{array}$ & $\begin{array}{l}7 \cdot 4(0 \cdot 2) \\
5 \cdot 2(0.9) \\
0 \\
<0.04\end{array}$ & $\begin{array}{l}10.9(0.2) \\
7.6(1.5) \\
0 \\
<0.05\end{array}$ & $\begin{array}{l}11 \cdot 1(0 \cdot 2) \\
7 \cdot 8(1 \cdot 2) \\
0 \\
<0 \cdot 02\end{array}$ & $\begin{array}{l}22.0(0.5) \\
15.4(2 \cdot 8) \\
0 \\
<0.03\end{array}$ \\
\hline
\end{tabular}

* Mean (SEM). †Summation of distal ileal and caecal blinded histological scores (0-4), as described in the methods section. $\ddagger$ Summation of acute and chronic score. \p Values: PG-APS/IL10 $v$ PG-APS/RSA group. 
TABLE III IL10 treatment suppresses extraintestinal inflammation and anaemia in the chronic phase (day 17) of the $P G-A P S$ model

\begin{tabular}{|c|c|c|c|c|c|}
\hline \multirow{2}{*}{$\begin{array}{l}\text { Groups } \\
\text { Gut injection/treatment }\end{array}$} & \multirow{2}{*}{$\begin{array}{l}\text { WBC } \\
\times 10^{9} \text { SI units } /\end{array}$} & \multirow{2}{*}{$\begin{array}{l}P C V \\
\%\end{array}$} & \multirow{2}{*}{$\begin{array}{l}\text { Liver weight } \\
\text { mg/g body weight }\end{array}$} & \multicolumn{2}{|c|}{ Hepatic granulomast } \\
\hline & & & & macroscopic & histological \\
\hline $\begin{array}{l}\text { PG-APS/RSA }(n=10) \\
\text { PG-APS/IL10 }(n=10) \\
\text { HSA/RSA }(n=5) \\
\text { p Value } \ddagger\end{array}$ & $\begin{array}{l}29 \cdot 7(2 \cdot 6)^{\star} \\
17 \cdot 3(1 \cdot 7) \\
7 \cdot 7(0 \cdot 4) \\
<0 \cdot 001\end{array}$ & $\begin{array}{l}37 \cdot 8(1 \cdot 0) \\
42 \cdot 7(1 \cdot 1) \\
48 \cdot 4(0 \cdot 7) \\
<0.004\end{array}$ & $\begin{array}{l}70 \cdot 5(4 \cdot 6) \\
56 \cdot 5(3 \cdot 6) \\
39 \cdot 7(1 \cdot 2) \\
<0.03\end{array}$ & $\begin{array}{c}80 \% \\
20 \% \\
0 \% \\
<0 \cdot 01\end{array}$ & $\begin{array}{l}80 \% \\
30 \% \\
0 \% \\
<0.025\end{array}$ \\
\hline
\end{tabular}

${ }^{\star}$ Mean (SEM); tincidence of hepatic granulomas; $\ddagger \mathrm{p}$ values PG-APS/IL10 $v$ PG-APS/RSA; §p values PG-APS/IL10 $v$ PG-APS/RSA calculated by $\chi^{2}$ test.
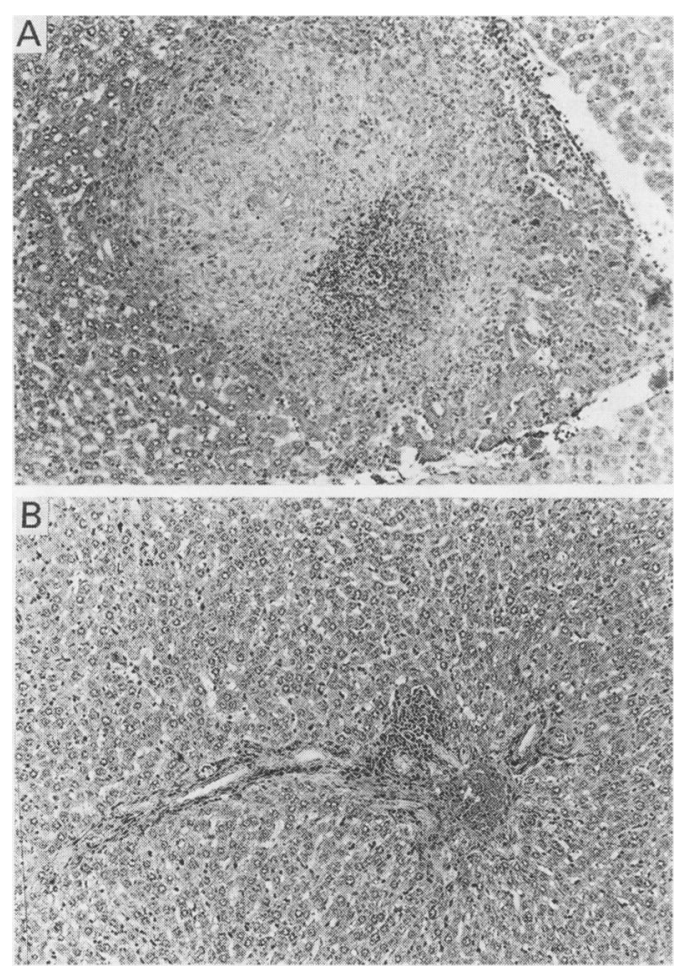

Figure 3: Histological demonstration of the liver architecture 17 days after subserosal $P G-A P S$ injection and $R S A$ treatment $(A)$ or continuous murine recombinant IL10 treatment (B). Only infiltration of mononuclear cells in the area of the portal tract are visible in liver sections of $P G-A P S / I L 10$ treated rats, whereas the livers of $P G-A P S / R S A$ treated rats show destruction of the architecture with granulomas (haematoxylin and eosin stain, original magnification $\times 20$ ).

Murine recombinant IL10 treatment suppressed the development of chronic arthritis in a highly significant fashion (Fig 4). On day 17 after PG-APS injection joints of IL10 treated rats were not significantly increased over HSA/RSA negative controls; the increase in the mean (SEM) joint diameter from preinjection values seen in the PG-APS/RSA group was reduced by nearly $80 \%(1.85(0.37) \mathrm{mm}$ in the PG-APS/RSA versus $0.38(0 \cdot 19) \mathrm{mm}$ in the PG-APS/IL10 treatment group, $\mathrm{p}<0.001$ ) (Fig 4). Only two of 10 animals showed clinical signs of arthritis after IL10 treatment with very attenuated arthritis in one of the two rats, whereas eight of 10 animals in the PG-APS/ RSA group clinically showed profound arthritis with marked swelling and erythema. The histopathology of the joints confirmed the clinical pattern. Figure 5 shows that infiltration of PMNs and mononuclear cells, pannus formation, cartilage erosion, bone degradation as well as exudation of cells into the joint space were clearly inhibited by IL10 treatment.

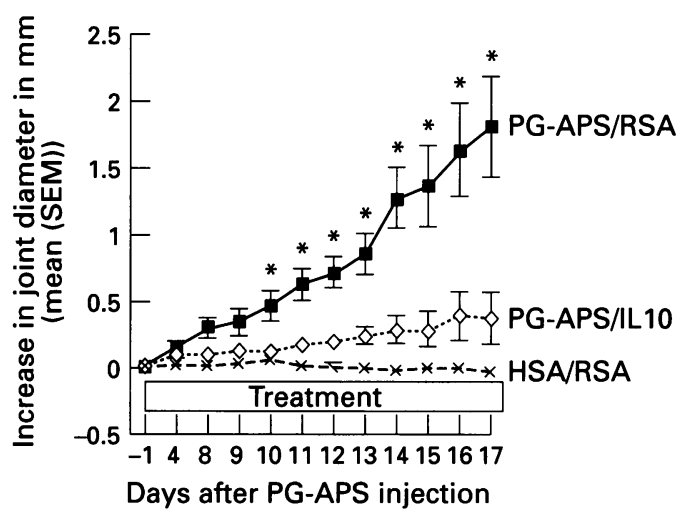

Figure 4: Effect of murine recombinant IL10 treatment on PG-APS induced arthritis. IL 10 (125 $\mu \mathrm{g} / \mathrm{kg}$ every 12 hours) was given subcutaneously starting 12 hours before $P G$-APS injection (12.5 $\mu \mathrm{g} / \mathrm{g}$ subserosally in the intestine) and continuing throughout the duration of the experiment $(n=10)$. Controls included rats injected intramurally with $P G-A P S(n=10)$ or HSA $(n=5)$ and treated with RSA (125 $\mu \mathrm{g} / \mathrm{kg}$ every 12 hours subcutaneously). foint measurements were carried out at indicated days after PG-APS injection. Foint diameter changes in $P G-A P S / R S A$ treated rats were significantly greater $\left({ }^{*} p<0.01\right)$ than $P G-A P S / I L 10$ treated rats at each interval after day 10.

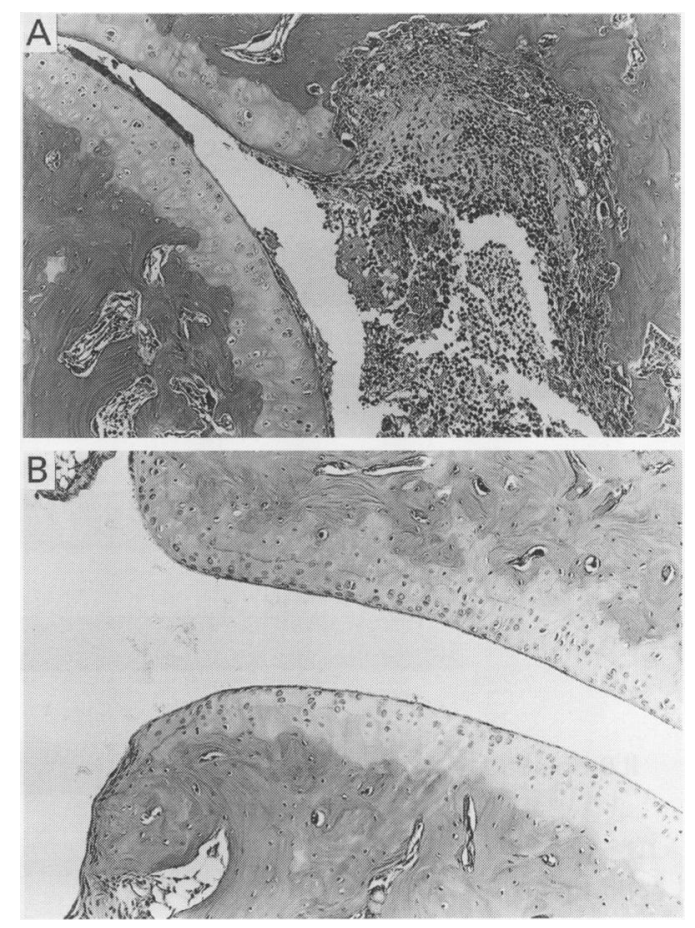

Figure 5: Representative joint tissues from rats treated with $R S A(A)$ or recombinant murine IL $10(B)$ for 17 days after intestinal subserosal PG-APS injection. IL10 treatment prevented clinical and histological $(B)$ onset of arthritis, whereas the histological section of only RSA treated rats show pannus formation with infiltration of neutrophils, and mononuclear cells, as well as cartilage destruction and bone erosion $(A)$ (haematoxylin and eosin stain, original magnification $\times 20$ ). 
Effects of IL10 treatment on cytokine regulation IL10 reduced or inhibited the expression of IL $1 \alpha$ and $\beta$, TNF $\alpha$, IL6, and IFN $\gamma$ genes in the liver, mesenteric lymph nodes, and caecal tissues as measured by RT-PCR. The most pronounced effects were seen in the liver consistent with the marked differences in hepatic granuloma formation (Fig 6). Expression of IL1 RA and IL10 mRNA (results not shown) did not differ between the IL10 treated and not treated groups; these cytokines were also constitutively expressed in non-inflamed HSA/RSA controls.

Earlier studies showed significantly increased IL $1 \alpha$ protein concentrations in caecal tissues in the chronic phase after PG-APS subserosal injection. ${ }^{17}$ IL10 treatment decreased IL $1 \alpha$ protein levels by $40 \%$ (Fig 7 ). Furthermore, we assessed the production of IFNy and IL2 by concanavalin A stimulated MLN cells, isolated 17 days after PG-APS injection. Whereas MLN cells showed no measurable spontaneous production of IFN $\gamma$ or IL2, concanavalin A stimulation upregulated the production of IFNy twofold and IL2 2.5-fold in PG-APS/RSA treated rats compared with HSA/RSA controls. However, concanavalin A stimulated MLN cells isolated from IL10 treated rats showed a $45 \%$ reduction of IFN $\gamma$ and IL2 production from PG-APS/RSA treated animals.

\section{Discussion}

This study shows that murine recombinant IL10 treatment successfully attenuated acute and chronic granulomatous inflammation induced by bacterial cell wall polymers and downregulated cytokine expression in vivo and in vitro. Continuous IL10 administration had

\section{IFN $\gamma$ bp 547}

IL $1 \alpha$ bp 362

IL1 $1 \beta$ bp 543

IL1RA bp 367

TNF $\alpha$ bp 692

IL6 bp 496

$\beta$ Actin bp 281

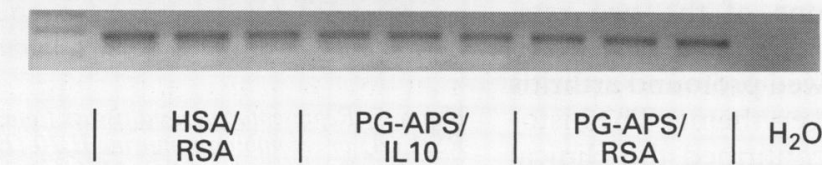

Figure 6: Gene expression of different cytokines in the liver of IL10 treated PG-APS injected animals compared with $P G-A P S / R S A$ and $H S A / R S A$ animals. Shown are three representative animals of each group. On day $17 R N A$ was isolated from liver tissues and $c D N A$ was amplified using RT-PCR for 23-40 cycles with rat cytokine specific primers. Aliquots of the products were visualised on a $2 \%$ agarose gel. To confirm a uniform amplification process $\beta$ actin was coamplified.

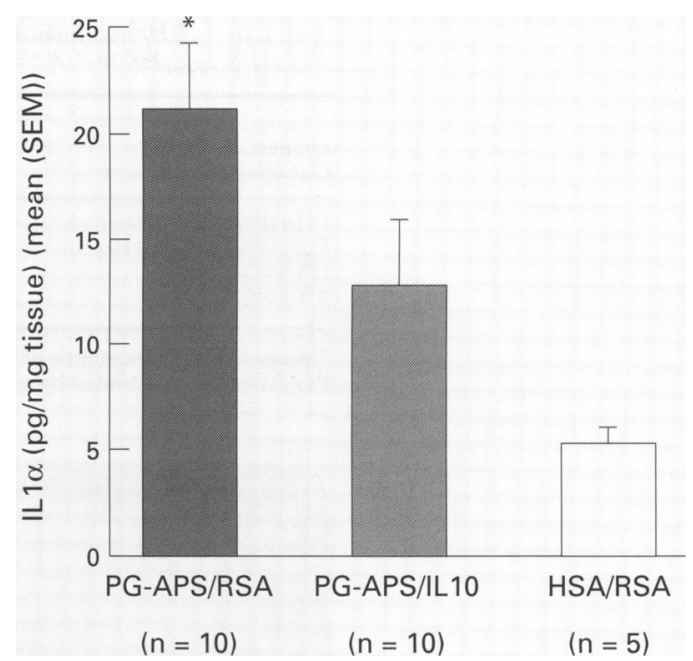

Figure 7: Caecal IL1 $\alpha$ protein levels measured by radioimmunoassay in caecal tissues 17 days after injection of $P G-A P S$ or $H S A$. IL1 $\alpha$ protein concentrations are expressed as mean (SEM). IL10 treatment inhibited IL1 $\alpha$, whereas PG-APS alone significantly increased caecal IL $1 \alpha$ protein levels compared with the HSA control group ( ${ }^{*}=p<0.003$ PG-APS/RSA HSA/RSA).

a greater effect on chronic, granulomatous enterocolitis than on the acute phase of inflammation. IL10 treatment significantly improved macroscopic, histological, and immunological parameters of chronic intestinal inflammation 17 days after PG-APS injection. The improvement in neutrophilic infiltration was less pronounced, as reflected by only minor changes of caecal tissue myeloperoxidase levels, although the acute histological score in the ileum (but not the caecum) was significantly decreased with IL10 treatment. These results suggest that IL10 treatment affects mononuclear cell (lymphocytes and macrophages) infiltration to a greater extent than neutrophils, in agreement with two previously published studies. ${ }^{14}{ }^{34}$ In murine acute pancreatitis IL10 did not influence cellular infiltration despite inhibiting tissue necrosis. ${ }^{14}$ Furthermore, IL 10 treatment did not improve the morphology or degree of cellular infiltrate in footpads injected with $\mathrm{Th} 1$ lymphocytes in a murine model of delayed type hypersensitivity, ${ }^{34}$ albeit IL10 inhibited footpad swelling by decreasing vascular permeability. Although we did not quantitate the degree of oedema or vascular leakage in this study, the significant improvement in acute macroscopic inflammation was mainly due to decreased bowel wall thickening, corresponding with observations in the delayed type hypersensitivity model.

The macroscopic and histological improvement of chronic inflammation by IL 10 treatment was accompanied by a down regulation of gene expression of monokines as well as IFN $\gamma$ in tissues, consistent with the ability of IL10 to inhibit expression of these cytokines by PG-APS stimulated splenocytes in vitro. These results agree with the ability of IL10 to inhibit macrophage and lymphocyte activation ${ }^{7}$ and to increase survival in a model of endotoxaemia by downregulating TNF $\alpha .^{13}$

The effects of IL10 treatment on in vivo gene expression of the monokines IL1, IL6, and $\mathrm{TNF} \alpha$ were most pronounced in the liver, in 
parallel with a marked inhibition of hepatic granulomas. Kupffer cells and newly recruited monocytes are important in the genesis of hepatic granulomas after intraperitoneal injection of PG-APS. ${ }^{35}{ }^{36}$ Kupffer cells rapidly clear these bacterial polymers from the circulation and large amounts of PG-APS remain in the phagolysosomes of these cells after 14-21 days. ${ }^{36}$ Our studies suggest that continuous IL10 administration to PG-APS treated rats downregulates monokine production by activated Kupffer cells and mononuclear phagocytes, thereby inhibiting formation of hepatic granulomas. This hypothesis is supported by in vitro studies showing that isolated Kupffer cells secrete IL1 and TNF $\alpha$ after stimulation with PG-APS ${ }^{36}{ }^{37}$ and that LPS or PG-APS stimulated $\mathrm{TNF} \alpha$ secretion by Kupffer cells can be inhibited by IL10 ( ${ }^{38}$ and H Herfarth, $\mathrm{S}$ Lichtman unpublished results).

IL10 nearly completely prevented chronic arthritis in this model, probably by down regulation of IL1, IL6 or TNF $\alpha$, as shown in the liver. A role for these macrophage products in the pathogenesis of experimental arthritis is demonstrated by reactivation of PG-APS induced arthritis by systemic injections of IL1 or TNF $\alpha$ and by induction of acute, transient arthritis by intraarticular injection of IL1 $\alpha$ or $\beta .{ }^{25} 3940$ Furthermore, treatment with recombinant IL1 RA or anti-TNF $\alpha$ antibody inhibits PG-APS induced arthritis, ${ }^{39}$ as does systemic treatment with TGF $\beta .^{41}$ In vitro TGF $\beta$ decreases LPS induced macrophage production of $\mathrm{TNF} \alpha$ and $\mathrm{ILl}$ to a similar extent as IL10, but inhibits cytokine translation in contrast with the activity of IL10 on transcriptional downregulation. ${ }^{42}$ IL1, IL6, and TNF $\alpha$ are also implicated in the pathophysiology of human rheumatoid arthritis ${ }^{5}$ and blocking endogenously produced IL10 in synovial cultures markedly increased these cytokines, suggesting an important immunoregulatory role of IL 10 in the joint. ${ }^{43}$ It is likely that IL10 has a similar key role in maintaining mucosal homeostasis, as targeted deletion of this cytokine leads to spontaneous intestinal inflammation. ${ }^{11}$

IL10 treatment more successfully inhibited extraintestinal inflammation in liver and joints than in the intestine, similar to the therapeutic effects of IL1 RA in this model. ${ }^{17}$ The amount of PG-APS in various organs may be a critical component because concentrations of this polymer are highest at intestinal injection sites. $^{24}$ Another variable is tissue concentrations of the administered IL10 within the various inflamed organs, which could not be measured in this study. Given the ability of PG-APS to activate multiple inflammatory pathways $^{19}$ and the redundancy of many immunological processes, ${ }^{444} 45$ treatment with IL10 alone might not be sufficient to completely suppress aggressive enterocolitis. An additional anti-inflammatory agent may be necessary to provide synergistic benefit. This concept is elegantly demonstrated by Powrie et al, who showed in a delayed type hypersensitivity model that the combination of IL4 and IL10 is more effective than monotherapy. ${ }^{46}$ In preliminary investigations, we have demonstrated additive activities of IL10 and corticosteroids in the PG-APS model. ${ }^{47}$

IL10 suppresses Th1 cytokine production ${ }^{48}$ as well as Th1 lymphocyte proliferation in vitro, ${ }^{49}$ if macrophages are used as antigen presenting cells. IL4, however, seems to be more important than IL10 in crossregulating a Th1 response towards a Th2 response. ${ }^{50}$ The crucial role of $T$ lymphocytes in chronic intestinal and systemic inflammation in the PG-APS model is well documented. ${ }^{20-22}{ }^{51}$ In our model in vivo IL10 treatment downregulated IFN $\gamma$ and IL2 protein secretion of mesenteric lymph nodes after Con A stimulation and inhibited tissue IFNy gene expression. Furthermore in vitro IL10 decreased IFN $\gamma$ upregulation in PG-APS activated splenocytes. Negative regulation of IFN $\gamma$ by IL10 is the suggested mechanism of disease prevention in the experimental allergic encephalomyelitis model $^{10}$ and in the non-obese diabetic mouse model. ${ }^{52}$

As shown here, IL10 downregulated expression of several pro-inflammatory cytokines in vivo. However, we cannot determine if these protective effects are direct or indirect through induction of other inhibitory cytokines, like IL1 RA, or by inhibition of pro-inflammatory mediators like IL12. IL1 RA, which attenuates PG-APS induced enterocolitis and systemic inflammation, ${ }^{17} 25$ is upregulated in the presence of IL10 in LPS activated neutrophils, ${ }^{53}$ whereas IL10 had no effect on IL1 RA production by mononuclear cells isolated from patients with rheumatoid arthritis ${ }^{54}$ or in vitro endotoxin stimulated whole blood from healthy volunteers after intravenous IL10 administration. ${ }^{55}$ In our study, tissue IL1 RA mRNA expression was not affected by IL10 treatment, but by downregulating IL1 production, IL10 increased the ratio between IL1 RA and IL1 towards a protective environment. A similar shift towards an immunosuppressive ratio of IL1 RA/IL1 was recently demonstrated in isolated mononuclear cells from patients with Crohn's disease exposed to IL10. ${ }^{56}$ IL10 also downregulates the pro-inflammatory cytokine IL $12,{ }^{57}$ which is involved in the pathogenesis of intestinal inflammation, as recently shown by the successful treatment of experimental colitis by IL 12 antibodies. ${ }^{58}$ IL 12 is secreted by activated macrophages and B cells and strongly increases IFN $\gamma$ production by $\mathrm{T}$ lymphocytes, thus shifting the immunological response towards a Th1 repertoire, as recently shown in a parasitic experimental model. ${ }^{59}$

The PG-APS model, which displays genetically determined host susceptibility, ileocaecal inflammation, extraintestinal manifestations of anaemia, leucocytosis, hepatobiliary inflammation, arthritis, and exhibits spontaneous relapses of inflammation, resembles many features of Crohn's disease. Furthermore, PG-APS is an environmentally relevant agent, which is present in high concentrations in the lumen of the distal ileum and colon. Ubiquitous anaerobic bacteria and their cell wall components seem to be involved in IBD 
and reactive arthritis. ${ }^{19}{ }^{60}$ Our results demonstrate that IL10 down regulates experimental chronic granulomatous inflammation induced by bacterial cell wall components in genetically susceptible hosts. In this model IL10 appears to act by suppressing the expression of monokines and IFN $\gamma$. Immunomodulating IL10 treatment could be a new effective therapeutic approach for chronic inflammatory diseases in humans, particularly Crohn's disease and rheumatoid arthritis, which are characterised by increased tissue concentrations of products of activated macrophages and Th1 lymphocytes. ${ }^{5461}$

This research was supported by NIH grants DK 40249 , DK 47700 and DK 34989, the Deutsche Forschungsgemeinschaft (He 2379/1-1; Ra 671/1-1), and partially supported by the Schering Plough Research Institute. The authors thank Roger Brown for preparation of PG-APS and Diane Bender, Roger Brown for preparation of PG-APS and D
Julie Mitchell and Lisa Holt for technical support.

Julie Mitchell and Lisa Holt for technical support.
Parts of this article were presented at the 46th Annual Parts of this article were presented at the 46th Annual
Meeting of the American Association for the Study of Liver Meeting of the American Association for the Study of Liver Disease, November 3-7, 1995 and
form in Hepatology 1995; 22: 364A.

1 Locksley RM. Th2 cells: Help for helminths. $f \operatorname{Exp} \mathrm{Med}$ 1994; 179: 1405-7.

2 Herfarth HH, Sartor RB. Cytokine regulation of experimental intestinal inflammation. Current Opinion in Gastroenterology 1994; 10: 625-32.

3 Sartor RB. Insights into the pathogenesis of inflammatory bowel diseases provided by new rodent models of spontaneous colitis. Inflammatory Bowel Disease 1995; 1: s4-75.

4 Sartor RB. Current concepts of the etiology and pathogenesis of ulcerative colitis and Crohn's disease. Gastroenterol Clin N Am 1995; 24: 475-507.

5 Sewell KL, Trentham DE. Pathogenesis of rheumatoid arthritis. Lancet 1993; 341: 283-6.

6 Atkinson MA, MacLaren NK. The pathogenesis of insulin dependent diabetes mellitus. $N$ Engl $\mathscr{f}$ Med 1994; 331 1428-36.

7 Mosmann TR. Properties and functions of interleukin-10. Adv Immunol 1994; 56: 1-16.

8 Bogdan C, Nathan C. Modulation of macrophage function by transforming growth factor beta, interleukin-4, and interleukin-10. Ann NY Acad Sci 1993; 00: 713-39.

9 Kennedy MK, Torrance DS, Picha KS, Mohler KM Analysis of cytokine mRNA expression in the central Analysis of cytokine mRNA expression in the central nervous system of mice with experimental autoimmune encephalomyelitis reveals that IL-10 mRNA expression
correlates with recovery. f Immunol 1992; 149: correlates

10 Rott O, Fleischer B, Cash E. Interleukin-10 prevents experimental allergic encephalomyelitis in rats. Eur $\mathcal{f}$ Immunol 1994; 24: 1434-40

11 Kühn R, Löhler J, Rennick D, Rajewsky K, Müller W. Interleukin-10 deficient mice develop chronic enterocolitis. Cell 1993; 75: 263-74.

12 Powrie F, Leach MW, Mauze S, Menon S, Caddle LB, Coffman RL. Inhibition of Th1 responses prevents inflammatory bowel disease in scid mice reconstituted with $\mathrm{CD}_{45 \mathrm{RB}^{\mathrm{hi}}} \mathrm{CD}^{+} \mathrm{T}$ cells. Immunity 1994; 1 : 553-62.

13 Gerard C, Bruyns C, Marchant A, Abramowicz D, Vandenabeele P, Delvaux A, et al. Interleukin-10 reduces the release of tumor necrosis factor and prevents lethality in experimental endotoxemia. $\mathcal{F}$ Exp Med 1993; 177 547-50.

14 Van Laethem JL, Marchant A, Delvaux A, Goldman M Robberecht $\mathrm{P}$, Velu $\mathrm{T}$, et al. Interleukin 10 prevents necrosis in murine experimental acute pancreatitis. Gastroenterology 1995; 108: 1917-22.

15 Kasama T, Strieter RM, Lukacs NW, Lincoln PM, Burdick MD, Kunkel SL. Interleukin-10 expression and chemokine regulation during the evolution of murine type II collagen-induced arthritis. F Clin Invest 1995; 95: 2868-76.

16 Wahl SM, Hunt DA, Allen JB, Wilder RL, Paglia L, Hand AR. Bacterial cell wall-induced hepatic granulomas. An in vivo model of $\mathrm{T}$ cell-dependent granulomas. An in vivo model of T

17 McCall RD, Haskill S, Zimmermann EM, Lund PK Thompson RC, Sartor RB. Tissue interleukin-1 and interleukin-1 receptor antagonist expression in enterocolitis in resistant

18 Cromartie WJ, Craddock JG, Schwab JH, Anderle SK, Yan $\mathrm{CH}$. Arthritis in rats after systemic injection of streptococcal cells or cell walls. F Exp Med 1977; 146 1585-602.
19 Schwab JH. Phlogistic properties of peptidoglycanpolysaccharide polymers from cell walls of pathogenic and polysaccharide polymers from cell walls of pathogenic and Immun 1993; 61: 4535-9.

20 Sartor RB, Bender DE, Allen JB, Zimmermann EM, Holt LC, Pardo MS, et al. Chronic experimental enterocolitis and extraintestinal inflammation are T-lymphocyte dependent. Gastroenterology 1993; 104 775A.

21 Allen JB, Malone DG, Wahl SM, Calandra GB, Wilder RL Role of the thymus in streptococcal cell wall-induced arthritis and hepatic granuloma formation. Comparative studies of pathology and cell wall distribution in athymic and euthymic rats. $\mathcal{F}$ Clin Invest 1985; 76: 1042-56.

22 Yocum DE, Allen JB, Wahl SM, Calandra GB, Wilder RI Inhibition by cyclosporin $A$ of streptococcal cell wallinduced arthritis and hepatic granulomas in rats. Arthritis Rheum 1986; 29: 262-73.

23 Stimpson SA, Schwab JH. Chronic remittent erosive arthritis induced by bacterial peptidoglycan polysaccharide structures. In: Chang JY, Lewis AJ, eds. Pharmalogical methods in the control of inflammation. New York: Liss, 1989: 381-94.

24 Sartor RB, Cromartie WJ, Powell DW, Schwab JH. Granulomatous enterocolitis induced in rats by purified bacterial cell wall fragments. Gastroenterology 1985; 89: 587-95.

25 Schwab JH, Anderle SK, Brown RR, Dalldorf FG, Thompson RC. Pro- and anti-inflammatory roles of interleukin-1 in recurrence of bacterial cell wall-induced arthritis in rats. Infect Immun 1991; 59: 4436-42.

26 Grisham MB, Benoit JN, Granger DN. Assessment of leukocyte involvement during ischemia and reperfusion of intestine. Meth Enzymol 1990; 186: 729-42.

27 Dijkema R, Van der Meide PH, Dubbeld M, Caspers MWJ, Schellekens H. Cloning, expression, and purification of rat IFN-gamma. Meth Enzymol 1986; 119: 453-63.

28 Eisenberg SP, Brewer MT, Verderber E, Heimdal P, Brandhuber BJ, Thompson RC. Interleukin-1 receptor antagonist is a member of the interleukin-1 gene family: evolution of a cytokine control mechanism. Proc Natl Acad Sci USA 1991; 88: 5232-6.

29 Feeser W, Freimark BD. Nucleotide sequence of rat prointerleukin- 1 beta mRNA. GenBank 1992; Accession: interleukin-1.

$30 \mathrm{Kwon}$ J, Chung I, Benveniste E. Cloning and sequence analysis of the rat tumor necrosis factor-encoding genes. Gene 1993; 132: 227-36

31 Nishida T, Nishino N, Takano M, Sekiguchi Y, Kawai K, Mizuno KU, et al. Molecular cloning and expression of rat interleukin-1 alpha cDNA. F Biochem 1989; 105: 351-7.

32 Northemann W, Braciak TA, Hattori M, Lee F, Fey GH. Structure of the rat interleukin 6 gene and its expression in macrophage-derived cells. $\mathcal{F}$ Biol Chem 1989; 264: 16072-82.

33 Nudel U, Zakut R, Shani M, Neuman S, Levy Z, Vaffe D. The nucleotide sequence of the rat cytosplasmatic betaactin gene. Nucleic Acids Res 1983; 11: 1759-71.

$34 \mathrm{Li} \mathrm{L}$, Elliott JF, Mosmann TR. IL-10 inhibits cytokine production, vascular leakage, and swelling during $T$ helper 1 cell-induced delayed-type hypersensitivity. f Immunol 1994; 153: 3967-78.

35 Kossmann T, Manthey CL, Brandes ME, Morganti KMC, Ohura K, Allen JB, et al. Kupffer cells express type I TGFbeta receptors, migrate to TGF-beta and participate in streptococcal cell wall induced hepatic granuloma formation. Growth Factors 1992; 7: 73-83.

36 Manthey CL Kossmann T, Allen JB, Corcoran ML Brandes ME, Wahl SM. Role of Kupffer cells in developing streptococcal cell wall granulomas. Streptococcal cell wall induction of inflammatory cytokines and mediators. Am $\mathcal{F}$ Pathol 1992; 140: 1205-14.

37 Lichtman SN, Wang J, Schwab JH, Lemasters JJ. Comparison of peptidoglycan-polysaccharide and lipopolysaccharide stimulation of Kupffer cells to produce polysaccharide stimulation of Kupffer cells to produce
tumor necrosis factor and interleukin-1. Hepatology 1994; 19: 1013-22.

38 Grewe M, Gausling R, Gyufko K, Hoffmann R, Decker K. Regulation of the mRNA expression for tumor necrosis actor- $\alpha$ in rat liver macrophages. $f$ Hepatol 1994; 20 : 811-8.

39 Schwab JH. Bacterial cell-wall induced arthritis: models of chronic recurrent polyarthritis and reactivation of monoarticular arthritis. In: Henderson B, Pettifer R, Edwards J, eds. Mechanisms and models in rheumatoid arthritis. London: Academic Press, 1995: 439-54.

40 Stimpson SA, Dalldorf FG, Otterness IG, Schwab JH. Exacerbation of arthritis by IL-1 in rat joints previously injured by peptidoglycan-polysaccharide. $\mathcal{F}$ Immunol injured by peptido

41 Brandes ME, Allen JB, Ogawa Y, Wahl SM. Transforming growth factor beta 1 suppresses acute and chronic arthritis
in experimental animals. $\mathcal{F}$ Clin Invest $1991 ; 87: 1108-13$.

42 Bogdan C, Paik J, Vodovotz Y, Nathan C. Contrasting mechanisms for suppression of macrophage cytokine release by transforming growth factor-beta and interleukin-10. F Biol Chem 1992; 267: 23301-8.

43 Katsikis PD, Chu CQ, Brennan FM, Maini RN, Feldmann $M$. Immunoregulatory role of interleukin 10 in rheumatoid arthritis. $\mathcal{F}$ Exp Med 1994; 179: 1517-27.

44 Sartor RB. Cytokines in intestinal inflammation: pathophysiological and clinical considerations. Gastroenterology 1994; 106: 533-9. 
45 Paul WE. Pleiotropy and redundancy: T cell-derived lymphokines in the immune response. Cell 1989; 57: $521-4$.

46 Powrie F, Menon S, Coffman RL. Interleukin-4 and interleukin-10 synergize to inhibit cell-mediated immunity in vivo. Eur f Immunol 1993; 23: 2223-9.

47 Herfarth HH, Mohanty S, Rath HC, Sartor RB. In vivo IL-10 treatment suppresses chronic granulomatous inflammation and proinflammatory cytokine expression in experimental enterocolitis, arthritis and hepatitis. Gastroenterology 1996; 110: A924.

48 Fiorentino DF, Bond MW, Mosmann TR. Two types of mouse T helper cell. IV: Th2 clones secrete a factor that inhibits cytokine production by Th1 clones. $f$ Exp Med 1989; 170: 2081-95.

49 Ding L, Shevach EM. IL-10 inhibits mitogen-induced $T$ cell proliferation by selectively inhibiting macrophage $T$ cell proliferation by selectively inhibiting macrophage
costimulatory function. $\mathcal{F}$ Immunol $1992 ; 148: 3133-9$

50 Paul WE, Seder RA. Lymphocyte responses and cytokines. Cell 1994; 76: 241-51.

51 Van Den Broeck MF, Van De Langerijt LG, Van Bruggen MC, Billingham ME, Van Den Berg WB. Treatment of rats with monoclonal anti-CD4 induces long-term resistance to streptococcal cell wall-induced arthritis. Eur $\mathcal{F}$ Immunol 1992; 22: 57-61.

52 Pennline KJ, Roque GE, Monahan M. Recombinant human IL-10 prevents the onset of diabetes in the nonobese diabetic mouse. Clin Immunol Immunopathol 1994; 71: 169-75.

53 Cassatella MA, Meda L, Gasperini S, Calzetti F, Bonora S. Interleukin $10(\mathrm{IL}-10)$ upregulates II-1 receptor antagonist production from lipopolysaccharide-stimulated human production from lipopolysaccharide-stimulated human degradation. $\mathcal{F} \operatorname{Exp}$ Med 1994; 179: 1695-9.
54 Hart PH, Ahern MJ, Smith MD, Finlay-Jones JJ. Comparison of suppressive effects of interleukin-10 and interleukin- 4 on synovial fluid macrophages and blood monocytes from patients with inflammatory arthritis. Immunology 1995; 84: 536-42.

55 Chernoff AE, Granowitz EV, Shapiro L, Vannier E, Lonnemann G, Angel JB, et al. A randomized, controlled trial of IL-10 in humans. Inhibition of inflammatory cytokine production and immune responses. F Immunol 1995; 154: 5492-9.

56 Schreiber S, Heinig T, Thiele HG, Raedler A. Immunoregulatory role of interleukin 10 in patients with inflammatory bowel disease. Gastroenterology 1995; 108: 1434-44.

57 Cassatella MA, Meda L, Gasperini S, D'Andrea A, Ma X, Trinchieri $G$. Interleukin-12 production by human polymorphonuclear leukocytes. Eur f Immunol 1995; 25: 1-5.

58 Neurath MF, Fuss I, Kelsall B, Stuber E, Strober W. Antibodies to interleukin 12 abrogate established Antibodies to interleukin 12 abrogate established experiment

59 Finkelman FD, Madden KB, Cheever AW, Katona IM, Morris SC, Gately MK, et al. Effects of interleukin 12 on immune responses and host protection in mice infected with intestinal nematode parasites. $\mathcal{F}$ Exp Med 1994; 179: 1563-72.

60 Sartor RB. Microbial factors in the pathogenesis of Crohn's disease, ulcerative colitis, and experimental intestinal inflammation. In: Kirsner JB, Shorter RG, eds. Inflammatory bowel disease. Baltimore: Williams and Wilkins, 1995: 96-124.

61 Simon AK, Seipelt E, Sieper J. Divergent T-cell cytokine patterns in inflammatory arthritis. Proc Natl Acad Sci USA $1994 ; 91$ : 8562-6. 